\title{
CONSIDERAÇÕES SOBRE A PROVA DA EXISTENNCIA DE DEUS ELABORADA POR HASDAI CRESCAS (1340-1411)
}

\author{
Alexandre Leone* \\ alexleone29@gmail.com
}

RESUMO Neste artigo,é exposto e discutido o caminho percorrido por Hasdai Crescas (1340-1411), filósofo judeu medieval que viveu em Barcelona, na elaboração de sua prova para a existência de Deus, formulada com base em sua crítica às provas apresentadas por Maimônides (1138-1204) no "Guia dos Perplexos". A crítica de Crescas parte da formulação de um conceito geral de existência aplicável tanto ao ser necessário quanto aos seres contingentes. Outro aspecto interessante em seu caminho para a elaboração da prova da existência de Deus é a distinção que ele faz entre quididade e existência no ser necessário, posição única entre os medievais e que introduz um importante aspecto de imanência em sua ideia de Deus, distinguindo-a radicalmente daquela defendida por Maimônides.

Palavras-chave Crescas, Maimônides, existência, quididade, imanência, transcendência.

ABSTRACT This article presents and discusses the path followed by Hasdai Crescas (1340-1411), medieval Jewish philosopher who lived in

* Doutor em cultura judaica pela Faculdade de Filosofia, Letras e Ciências Humanas da Universidade de São Paulo (FFLCH-USP), pós-doutorado em filosofia pela mesma instituição, professor do Centro Universitário Salesiano de São Paulo (UNISAL), professor convidado do Departamento de Letras Orientais (DLO) e pesquisador do Centro de Estudos Judaicos, ambos da USP. Artigo recebido em 10/06/2014 e aprovado em 12/08/2014. 
Barcelona for the elaboration of his proof for existence of God, formulated from his critique of the evidence presented by Maimonides (1138-1204) in the "Guide of the Perplexed". Crescas's critique starts with the formulation of a general concept of existence applicable to both the necessary being as to the contingent beings. Another interesting aspect of his way to formulate his proof is Crescas's distinction between existence and quiddity in the necessary being, a unique position among the medieval philosophers that introduces an important aspect of immanence in his idea of God, which radically differs from that advocated by Maimonides.

Keywords Crescas, Maimonides, existence, quiddity, immanence, transcendence.

\section{Distinção entre quididade e existência em Deus}

Na terceira seção do primeiro tratado de "Or Hashem” (“Luz de Deus”), Hasdai Crescas conclui sua crítica a Maimônides ao completar a análise das provas para a existência, a unidade e a incorporeidade de Deus apresentadas no "Guia dos Perplexos". Esse caminho chegará ao final do primeiro tratado com sua abordagem do significado do amor divino. Numa retrospectiva da senda trilhada por Crescas ao longo do primeiro tratado de "Or Hashem", é possível notar que ele segue um caminho dialético no qual, nesse primeiro tratado, debate com Maimônides e, por extensão, com outros filósofos aristotelizantes medievais árabes e judeus. É assim que Crescas, na primeira seção das três que compõem o primeiro tratado de seu livro, expõe os argumentos adversários em prol das 26 proposições e as provas da existência de Deus tal como entendidas à luz dos comentadores avicenianos e averroístas de Maimônides. Crescas debate tanto com a posição aristotelizante elaborada por Avicena, modulada por elementos neoplatônicos, quanto com a de Averróis, que se distancia dos elementos neoplatônicos em prol de uma releitura de Aristóteles.

Na segunda seção do primeiro tratado de "Or Hashem", são feitas então a crítica das 26 proposições e a das provas para a existência divina apresentadas no "Guia". O resultado dessas críticas implica a rejeição da física aristotélica, tal como recebida na tradição da filosofia medieval árabe e judaica, mas Crescas não debate somente com esses autores, cujas obras estavam disponíveis em hebraico em seu tempo, para chegar a essa nova física. Além da relação com a falsafa, o debate antiaristotélico latino ecoa em Crescas. Shlomo Pines e os pesquisadores que seguem sua abordagem veem também, em "Or Hashem", 
um diálogo e um debate em voz baixa, nas entrelinhas, com diversos filósofos escolásticos latinos, em especial com Duns Escoto, Jean Buridan e Nicolau Oresme. São esses os latinos cujas obras refletem os ecos das condenações de Paris de 1277. No campo das literaturas sapienciais judaicas do medievo, há ainda em Crescas a recepção de fontes oriundas da literatura mística e da talmúdica, ambas cultivadas em seu tempo em Aragão e na Provença. O diálogo com essas fontes é menos velado que aquele travado com os latinos. $\mathrm{O}$ interessante é que essas tradições sapienciais judaicas não filosóficas refletem, como nos escritos de autores do círculo de Girona, elementos de uma recepção eclética de ideias tanto neoplatônicas quanto estoicas (Freudenthal, 1998). De todo esse complexo caminho emerge a física esboçada por Crescas, que defende a possibilidade de um universo infinito e eterno formado por mundos finitos, em que o vácuo é o lugar geral de todos os corpos. Ao final, as noções aristotélicas de que o meio é necessário para que ocorra o movimento e a de lugar natural para onde os elementos tenderiam também são rejeitadas.

$\mathrm{Na}$ terceira seção do primeiro tratado, ao concluir seu percurso caracterizado por uma forma de debater que agrega elementos da dialética talmúdica e talvez da disputatio latina, Crescas apresenta finalmente suas provas para a existência, a unidade e a incorporeidade divinas. Essa apresentação das provas foi precedida e está embebida de uma veemente crítica à metafísica aristotelizante medieval, cujo resultado, no pensamento de Crescas, é esboçar, além daquilo que Wolfson (1971) caracterizou como nova física, a prenunciar aquela do Renascimento, também uma nova metafísica que entende Deus, sua existência e unidade, de modo muito diferente do Deus radicalmente transcendente do "Guia dos Perplexos" e do "Mishné Torá". A ideia da transcendência divina era então tradição havia muito estabelecida nos círculos filosóficos judaicos de seu tempo. Na metafísica formulada por Crescas, Deus, apesar de sua quididade ser considerada inefável, incompreensível e transcendente, também apresenta aspectos de imanência, como sua presença, existência e em sua atualidade como causa primeira constante geradora de infinitos efeitos. Deve-se notar que essa metafísica já é esboçada por Crescas na segunda seção do primeiro tratado, em que Deus é apresentado como lugar do universo, que é todo preenchido por sua Presença (kavod), e também como causa primeira imanente a cada elemento da série infinita de causas e efeitos. No entanto, é na terceira e última seção que finalmente são elaboradas as relações entre quididade e existência, atualidade e unidade, e também a questão de se os atributos essenciais divinos devem ser conhecidos pela via negativa de Maimônides ou por outra via apresentada em suas teses. No auge do debate com Maimônides, Crescas defenderá a tese em prol dos infinitos atributos 
essenciais divinos, e então termina a terceira seção com sua discussão sobre a felicidade e o amor divinos. É por essa via que esboça sua teologia divergente daquela elaborada por Maimônides.

Crescas começa a enfocar o tema da existência de Deus distinguindo, mas também relacionando os conceitos de quididade e existência. Quididade, a essência de algo, é dita mahut no jargão filosófico hebraico medieval. Nesse mesmo hebraico filosófico medieval, existência é dita metziut. Mahut מהות, como será explicado de modo mais detalhado adiante, corresponde a um substantivo abstrato derivado da preposição interrogativa "mah" (o que) em hebraico. Metziut מציאות, outro substantivo abstrato, deriva da mesma raiz de matzá מצא: encontrar, deparar-se; usualmente, nos textos filosóficos hebraicos medievais, significa existência. O uso dessa raiz para denotar existência é anômalo no hebraico até então e tem sua origem no decalque do termo usado na filosofia árabe. Outros sinônimos de existência usados nos textos medievais, como esclarece Wolfson (1916, pp. 186-189, nota 86), são hiut היות ou ieshut הוה Eove interessante que este último foi também comumente usado nos textos místicos, como no Guinat Egóz, de Yossef Gikatila (séc. XIII). Crescas prefere usar o termo metziut, mais comum no vocabulário filosófico hebraico medieval, bem como também aparece nas traduções hebraicas dos escritos de Maimônides.

É nesse momento de sua reflexão que ele enfoca finalmente esse debate clássico medieval. Qual é o sentido da afirmação "Deus existe"? Para responder a essa pergunta, muitos medievais partiam do pressuposto de que, no caso de Deus, sua existência deve ser considerada idêntica à sua essência. Esse era quase um lugar-comum aceito então tanto entre árabes quanto entre judeus e latinos. É desse modo que refletir sobre o que deve ser entendido por existência e por quididade e se tais conceitos são ou não idênticos no ser necessário precedem a enunciação por parte de Crescas de sua prova para a existência de Deus em $O H$ 1,3,2. Nessa discussão acerca da relação entre quididade e existência, ambas terminam por ser distinguidas, uma da outra, não apenas nos seres em geral, mas até em Deus. Outra discussão empreendida por Crescas antes de enunciar sua prova para a existência de Deus é sobre se o conceito de existência aplicado ao ser necessário deve ser tão radicalmente distinguido da existência do conjunto dos seres contingentes. Será que um atributo como existência tem, entre Deus e os seres em geral, uma relação de homonímia ou de anfibologia, isto é, será que a existência é predicada a Deus e aos seres de maneiras radicalmente distintas, sem nenhuma relação entre eles, ou, pelo contrário, a existência deve ser predicada a Deus e aos seres do mesmo modo, ainda que com diferença de grau ou de prioridade ontológica? A questão aqui 
é se há um conceito geral de existência ou não, como propõe Maimônides. Em outras palavras, é ou não a existência de Deus completamente transcendente com relação à existência dos seres contingentes?

Refletindo sobre o que é a quididade divina, escreve Crescas:

עליו מבעלי העיון ומכתובי התורה, שהוא נעלם תכלית ההעלם, באופן שהשגת

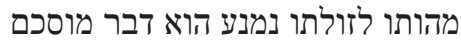

A opinião comum entre os pensadores racionalistas e os versados na Torá é que [a quididade divina] é absolutamente esquiva (neelam takhlit hahaelem), de sorte que a percepção de sua quididade (mahuto) é impossível a outro além dele. $(\mathrm{OH} \mathrm{1,3,1)}$

Conforme já mencionado, o termo hebraico usado nessa passagem por Crescas para quididade é מהות mahut, um substantivo construído a partir da preposição interrogativa "mah", que em hebraico significa "o que" unido ao sufixo $u$ t, usado para dar o sentido de substantivo abstrato. Trata-se de um termo que surge no hebraico medieval. É notável como o termo português "quididade", também cunhado pelos latinos medievais, tenha sentido semelhante. Ambos os termos - quididade e mahut - são usados para traduzir o vocabulário aristotélico quando o estagirita pergunta sobre o que é a coisa, ou seja, o que é definição, isto é, sua essência. Em outras passagens, Crescas usa o termo etzem, que originalmente em hebraico significa "osso", mas que também é usado nos textos filosóficos medievais para dizer essência. Crescas principia esse trecho aparentemente concordando com Maimônides e com o conjunto da tradição filosófica medieval ao afirmar que a quididade ou a essência divina é neelam takhlit hahaelem, literalmente, oculta para além de todo limite de ocultação. Assim, nenhum outro ser além do próprio Deus pode ter a compreensão de sua quididade e abarcá-la com o intelecto. Nesse sentido, a essência divina é também, para Crescas, considerada transcendente.

Contudo, essa concordância inicial com Maimônides logo é problematizada por meio do debate sobre a interpretação da passagem bíblica, em Êxodo 33:11-20, na qual Moisés roga a Deus que lhe revele sua Glória:

\footnotetext{
${ }^{11}$ E falava YHWH a Moisés face a face, como qualquer fala com o seu amigo [...].

${ }^{13}$ Agora, pois, se tenho achado graça aos teus olhos, rogo-te que me faças saber o teu caminho, e conhecer-te-ei, para que ache graça aos teus olhos; e considera que esta nação é o teu povo.

$[\ldots]$

${ }^{17}$ Então disse o YHWH a Moisés: Farei também isto, que tens dito; porquanto achaste graça aos meus olhos, e te conheço por nome.

${ }^{18}$ Então ele disse: Rogo-te que me mostres a tua Glória.
} 
${ }^{19}$ Porém ele disse: Eu farei passar toda a minha bondade por diante de ti, e proclamarei o nome do YHWH diante de ti; e terei misericórdia de quem eu tiver misericórdia, e me compadecerei de quem eu me compadecer.

${ }^{20} \mathrm{E}$ disse mais: Não poderás ver a minha face, porquanto homem nenhum verá a minha face, e viverá.

Maimônides (Guia, I, 54) utiliza-se dessa passagem bíblica para afirmar que a Escritura apoia sua ideia de que Deus tem uma existência radicalmente transcendente, isto é, a substância divina é totalmente diferente da substância do mundo. É desse modo que ele interpreta Êxodo 33:18 - em que Moisés se dirige a Deus com "Rogo-te que me mostres a tua Glória" - ao entender a frase como a súplica feita por Moisés para que Deus lhe permitisse compreender a essência divina e a resposta de Deus de que esta é inatingível e além da compreensão. No contexto daquele capítulo do "Guia", essa passagem bíblica é interpretada como um ensinamento profético transmitido por intermédio de Moisés de que, enquanto a essência divina está além de toda compreensão, somente por seus caminhos, isto é, por meio de suas ações, é que Deus pode ser conhecido. As ações divinas não são atributos essenciais, mas, segundo Maimônides, são os meios pelos quais os seres humanos podem obter algum conhecimento sobre Deus. No entanto, ao responder a Moisés "Não poderás ver a minha face" (Êxodo 33:20), Deus estaria afirmando, assim, a absoluta transcendência de sua essência. Para Maimônides, somente os atributos de ação, que não são verdadeiros atributos de Deus, mas sim caminhos pelos quais sua influência é testemunhada, são acessíveis aos homens.

Crescas questiona essa interpretação perguntando como o príncipe dos profetas poderia ignorar a impossibilidade de conhecer a quididade divina, clara a qualquer filósofo principiante, quando ele mesmo teria chegado a um grau de elevação maior do que todos os profetas e sábios? Como Maimônides justificaria a ignorância de um princípio tão básico por parte de Moisés? Crescas especula que Maimônides poderia responder a essa objeção supondo que Moisés não teria de fato rogado a Deus para revelar sua essência, mas essa passagem seria apenas uma visão que teria ocorrido a Moisés, num transe profético, para que por meio dela fosse ensinado que a quididade divina é

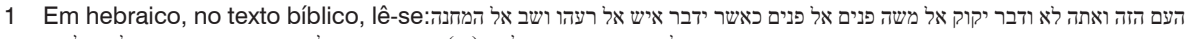

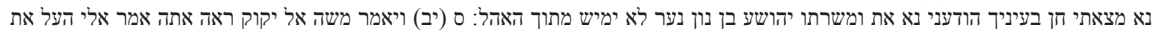

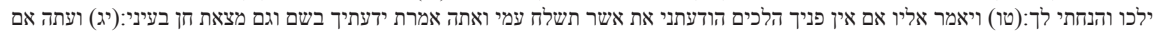

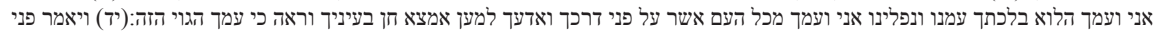

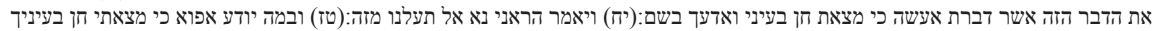

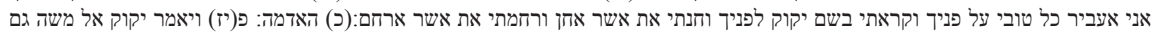

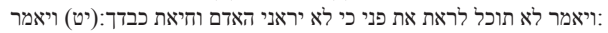


incognoscível. No entanto, contra-argumenta Crescas: "esta interpretação do versículo é contrária à da maior parte dos comentadores" $(\mathrm{OH} 1,3,1)$. De fato, três dos mais importantes comentadores medievais dessa passagem bíblica - Rashi (séc. XI), Abraham ibn Ezra (séc. XII) e Nahmanides (séc. XIII) -, muito conhecidos no período e na região onde viveu Crescas, divergem da interpretação de Maimônides, pois interpretam a passagem à luz do versículo "E falava o YHWH a Moisés face a face" (Êxodo 33:11). A expressão "face a face" (panim el panim) é interpretada na agadá e em vários midrashim com o significado de que Moisés, ao contrário de todos os outros profetas, não profetizava em transe. Rashi, França (séc. XI), por exemplo, escreve em seu comentário que Deus:

ומתמלל עם משה

Reúne-se com Moisés como alguém que está em uma conversa aberta (ou em uma reunião). ${ }^{2}$

O exegeta e filósofo sefardi Abraham Ibn Ezra, em seu longo comentário ao versículo "Rogo-te que me mostres a tua Glória" (Êxodo 30:18), diferenciase de Rashi, pois nega que a profecia mosaica ocorresse por meio de um diálogo feito por palavras, como o rabino francês parece sugerir, mas Ibn Ezra também conecta a passagem à expressão "face a face" (Êxodo 30:11), refletindo que, não sendo Deus corpo, ${ }^{3}$ esse não pode se tratar de um diálogo por meio de palavras:

גם ודבר ה' אל משה איננה בפה, רק הוא הדבור האמתי, כי דבור הפה דמיון הוא

Apenas a palavra de Deus a Moisés por não ser oral é o discurso verdadeiro, pois o discurso oral é apenas um simulacro do primeiro. $(O H 1,3,1,2011)$

Ibn Ezra considera tal experiência profética uma transmissão direta de Deus ao intelecto de Moisés, feita por meio não oral, diretamente ao intelecto humano: 
מלאך. וטעם כאשר ידבר איש אל רעהו (יא) - שלא היה על יד שליח שהוא מלאך. וזה דבור עם יוצר

E a razão é dada pelo versículo "como qualquer fala com o seu amigo" (Êxodo 33:11), pois não era por meio de um emissário que fosse o mensageiro (o veículo). Assim como a palavra na criação não é por meio de um anjo.

Apoiando-se nesses comentadores, a tese de Maimônides de que Moisés, nessa passagem, estaria num transe profético tendo uma visão e nela rogando a Deus que lhe revelasse sua essência é disputada por Crescas. Em seu próprio comentário, ele lembra que, em várias outras passagens bíblicas, é repetido que a profecia mosaica ocorria face a face, ou seja, não se dava na forma de visões, mas quando o príncipe dos profetas estava desperto. Desse modo, conclui Crescas:

ולא בקש משה השגת המהות לעולם.

Moisés jamais pediu para contemplar a essência divina. $(O H$ 1,3,1, 2011)

$\mathrm{Na}$ retórica de sua argumentação, Crescas afirma que saber que a essência divina é incompreensível é uma conclusão simples, entendida até pelos iniciantes em filosofia, quanto mais por um grande sábio e profeta. Além de tirar o peso da interpretação de Maimônides ao retratá-la como opinião minoritária, essa discussão sobre a exegese daquela passagem bíblica serve a Crescas para distinguir as noções de quididade e de existência em Deus. Na continuidade de sua argumentação, Crescas conclui que, enquanto a existência de Deus é algo que pode ser revelado ao intelecto, sua quididade é neelam takhlit hahaelem, oculta para além de todo limite de ocultação. A conclusão de Crescas é de que a existência e a essência em Deus não são a mesma coisa. Assim, não é apenas nos seres contingentes que tal distinção ocorre, mesmo no ser necessário tais conceitos permanecem diferentes um do outro. Enquanto a existência divina pode ser compreendida pelo intelecto humano, sua essência permanece sempre oculta. Desse modo, o que Moisés teria pedido, segundo a interpretação de Crescas da passagem, era para compreender Deus como העלה לכלל הנמצאות - a causa de todos os seres $(O H$ 1,3,1, 2011) - e para conhecer seus atributos essenciais. Interessante que, como veremos mais adiante, o enunciado de sua prova para a existência de Deus tem como peça central a ideia de Deus como causa primeira e necessária de todos os seres. Também é interessante notar que a Glória (Kavod), na segunda seção do primeiro tratado $(O H 1,2,1)$, é entendida como o aspecto imanente da divindade, que se dá como presença constante que 
preenche todo o universo infinito e como atualidade da existência divina, não necessariamente de sua essência. Em $O H$ 1,2,1, ela é inclusive relacionada à ideia de que Deus é "o Lugar" do universo na explicação do nome divino rabínico Ha-Makom. Sobre a Glória (Kevod YHWH), Crescas escreve que ela preenche o mundo tal como o vácuo infinito preenche os corpos. Vemos que a noção de existência em Crescas é construída de modo que a aproxima da ideia de imanência divina. O sentido desse debate travado aqui com Maimônides é embasar filosoficamente a opinião que Crescas tem em comum com vários autores ligados ao círculo cabalista de Girona, para quem essência se refere ao aspecto oculto e existência ao aspecto revelado da divindade. Essa tese está, porém, em completa divergência com a tradição aristotélica medieval, que afirmava que existência e quididade em Deus se reúnem numa unidade indistinguível. No entanto, quididade e existência são diferenciadas na divindade com base em tal posição, que já havia aparecido na cabala medieval antes de Crescas. A distinção entre um aspecto oculto contraposto a outro revelado no seio da divindade não tinha, porém, até então, recebido fundamentação filosófica. Eis o aporte de Crescas para esse debate.

\section{Quididade e existência dos seres em geral}

O passo seguinte de Crescas é mostrar que, entre os principais comentadores da tradição aristotélica medieval árabe e judaica, há uma importante controvérsia (makhloket) no que concerne ao modo de entender a relação entre essência e existência. Essa controvérsia entre os "comentadores de Aristóteles" - מחלקת בו בין מפרשי ספרי אריסטו - é apresentada como aquilo que, no Talmud, é uma disputa de tanaim, ou seja, uma controvérsia que não tem como ser respondida pelos debatedores nos marcos de suas premissas; no caso, o aristotelismo medieval. Esse recurso retórico é usado aqui a fim de ressaltar que, nesse ponto crucial, a inexistência de unanimidade sobre o entendimento desses dois conceitos se deve a inconsistências nas posições mantidas em ambos os lados da disputa. Crescas põe então, de um lado, Avicena, Al-Ghazâli e Maimônides, que consideram que a existência é distinta da quididade e que a primeira é um acidente da segunda nos seres em geral e idênticas uma à outra em Deus; de outro lado, estão Averróis e seus seguidores, entre eles Gersônides e Narboni, que consideram que a existência não é distinta da quididade em nenhum ser.

É importante ressaltar que a distinção entre essência e existência não se encontra em Aristóteles. No entanto, na leitura neoplatonizante que Avicena faz da "Metafísica" II, é introduzida essa distinção, que passa a ser uma 
característica do aristotelismo medieval transmitida dos árabes aos judeus e aos latinos. Maimônides segue e enfatiza a distinção conceituando a existência como acidente da substância; a existência seria por isso mesmo uma espécie de acessório para a quididade do existente, isto é, do ser. O comentário de Avicena (2007, pp. 211-219) à "Metafísica" II estabelece como coisa óbvia e necessária que, em tudo aquilo que tem uma causa para existir, sua existência é algo acrescentado à sua quididade. O ser contingente, isto é, cuja causa está em outro, é assim também entendido como meramente potencial com relação à sua existência. Isso porque sua existência é meramente uma possibilidade que pode ou não estar em ato. Todavia, a existência de Deus é necessária, pois não tem causa. Assim, nesse único caso, existência e essência convergem. Em Deus, sua essência é sua existência, isso porque a essência não é uma mera essência possível que aconteceu de existir em ato, de modo que sua existência seria um acessório da quididade (Maimônides, Guia I, 57, 2004). Segundo Avicena, apenas no caso de Deus sua existência é necessária, pois coincide com sua essência; todo o restante das criaturas tem somente a existência possível, que é um acidente de suas quididades. Por isso, a existência de Deus é qualitativamente diferente da existência comum dos seres contingentes.

Aproximando-se de Aristóteles, Averróis não aceita que ser e essência estejam separados (sejam distintos) nem nas criaturas nem em Deus. No entanto, se a essência divina é diferente das essências das criaturas, então sua existência é também de ordem diferente da dos outros seres. Segundo a tese de Averróis, o ser e a quididade são uma e a mesma coisa, por isso não há sentido geral da palavra "ser" (Smilevitch, 2010). O significado de "ser" é determinado por cada quididade particular. Assim, a existência de Deus é absolutamente diferente da existência de outro ser. É o que reconhece Crescas ao comentar que, para Averróis,

ולזה הוא מחויב, שה"נמצא" יאמר על האלוה יתברך ועל זולתו בשתוף השם הגמור , ולא במין ממיני

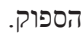

isso implica que o termo "existência" é empregado com relação a Deus, abençoado seja, e com relação a qualquer outro ente que não ele de forma completamente homonímia (beshituf hashem hagamur), sem nenhuma anfibologia (sipuk). (OH $1,3,1)$

Os dois conceitos empregados nessa passagem por Crescas - homonímia (shituf hashem) e anfibologia (sipuk) - são descritos por Maimônides (2011b) no capítulo 13 de Milot Hahigaion, livro que é dedicado por ele à discussão das categorias lógicas. Nesse capítulo, Maimônides descreve homonímia (shituf hashem) como o uso do mesmo termo para dois seres que são radicalmente 
diferentes, sem nenhuma comunidade entre si. Segundo Maimônides, quando um termo é aplicado a coisas diferentes que não se relacionam, é um termo homônimo, como no exemplo da palavra hebraica ain (olho), usada tanto para nomear o órgão da visão quanto uma fonte ("olho") de água. Não há vínculo, a não ser o uso da mesma palavra para se referir a duas realidades, sem nenhum vínculo formal. Já anfibologia (sipuk) ocorre quando temos o uso do mesmo nome para duas coisas que têm entre si algum atributo em comum, sem que, no entanto, esse atributo comum implique a comunidade de essência entre elas. Assim, a anfibologia implica inerentemente uma relação ambígua que é usada para significar duas realidades ou mais por causa de certa semelhança que guardam entre si, apesar de essa semelhança não implicar a identidade entre suas quididades. O exemplo dado por Maimônides é a palavra "homem", que tanto é usada para se referir a Rúben, uma pessoa, ente vivente e pensante, quanto para se referir à forma de um homem esculpido em madeira.

Assim, enquanto para Maimônides há dois tipos de existência - a dos seres contingentes, cuja existência é um acidente da quididade, e a do ser necessário, cuja existência e quididade são o mesmo -, para Averróis cada quididade distinta implica uma existência diferente. Maimônides aplica o conceito de homonímia para descrever a total separação entre a existência divina e a existência das criaturas. Em Averróis, essa homonímia é ainda mais radical (Smilevitch, 2010). Em ambos os casos, porém, a homonímia implica radical transcendência divina e distinção de substâncias.

No caso da tese de Averróis, como, com base nela, pergunta Crescas, será possível compreender o significado de predicar algo como existente quando empregado em relação à divindade ou a qualquer outro ente $(\mathrm{OH} 1,3,1)$ ? $\mathrm{Na}$ afirmação "Deus existe", por exemplo, o sentido desse enunciado fica fechado em si mesmo e torna-se tautológico. Como interpreta Waxman (1920, p. 63) acerca dessa crítica de Crescas, "se a existência é idêntica à essência, então o que ela agrega como predicado"? Se a existência e a quididade são a mesma coisa, então essa afirmação seria igual a dizer "Deus é Deus". Do mesmo modo, dizer que o "homem existe" seria o mesmo que dizer o "homem é o homem", e assim para qualquer outro ente. Nenhum juízo sobre a existência seria mais possível, pois estaria resumido à afirmação de uma definição (Smilevitch, 2010, pp. 470-471, nota 3).

Por outro lado, no caso da tese de Avicena e de Maimônides, segundo a qual a existência é apenas um acidente da quididade, a crítica que faz Crescas é a de que todo acidente implica um substrato, mas esse substrato também precisa existir anteriormente à existência que lhe é predicada. Essa existência anterior, por sua vez, também implica um substrato, ou seja, isso levaria à 
necessidade de postular uma existência anterior à existência até o infinito. Interessante que, apesar de argumentar em prol do infinito atual, esse tipo de regressão ao infinito é sempre rejeitado por Crescas como mera falácia e tautologia.

\section{Existência como caractere intrínseco da quididade}

A conclusão de Crescas é de que a existência não pode nem ser mero acidente da quididade, algo agregado a ela, conforme postulam Avicena e Maimônides, nem completamente idêntica à quididade, segundo postula Averróis $\left(O H\right.$ 1,3,1, 2011). ${ }^{4} \mathrm{O}$ que é então a existência? A resposta a essa pergunta é interessante. Para Crescas, apesar de que não deva ser compreendida como a essência nuclear (etzem) da quididade, a existência precisa ser entendida como caractere essencial (atzmi) da quididade. De acordo com Crescas:

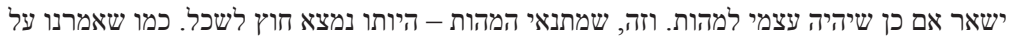
דרך משל שמהות האדם החיות והדיבור , הנה מתנאי המהות שמתות שיהיה נמצא חוץ לשכל.

Portanto, [a existência] deve ser um caractere essencial da quididade (atzmi lamahut). Com efeito, é pertinente às condições intrínsecas da quididade (mitnae hamahut) existir fora do intelecto (heioto nimtzá hutz la-sekhel). Como declarávamos, por exemplo, que a quididade do homem são a vida e a fala, eis que pertence às condições intrínsecas [desta] quididade (me-tnae ha-mahut) existir fora do intelecto. $(\mathrm{OH}$, $1,3,1,2011)$

Ao afirmar que a existência é um caractere essencial da quididade, Crescas entende que a existência é uma das manifestações intrínsecas da quididade, implicando com isso que há outras manifestações essenciais da quididade. O conceito de quididade é, assim, sempre mais abrangente que o de existência e não pode ser, como postulam Averróis e seus discípulos, reduzido apenas a um único caractere, tampouco a um caractere tão importante quanto o de existência, sob o ônus de com isso se fazer uma tautologia, que destrói o sentido do que é a quididade como conceito. A pergunta sobre o que é uma coisa não é respondida apenas pela constatação de sua existência. Conforme vimos antes, para Crescas, nem mesmo em Deus quididade e existência são o mesmo conceito. Nos seres em geral, a quididade é uma intelecção sobre o que é aquilo que está diante de nós. Todavia, a quididade não se manifesta apenas ao intelecto; um aspecto importante da manifestação de um ser se dá 
fora do intelecto (hutz la-sekhel) como manifestação sensorial e intuitiva que ocorre quando deparamos com ele como determinação atualizada e encontrada (nimtzá) fora de nós. A isso corresponde o conceito de existência. É necessário enfatizar que, para Crescas, entender a existência como manifestação da quididade para fora do intelecto é diferente tanto de entendê-la como acidente da quididade, como fazem Avicena e Maimônides, quanto de entendê-la como idêntica à quididade, como faz Averróis. A existência não é agregada à quididade de fora nem completamente idêntica a ela, é apenas uma de suas manifestações. Se é assim, então se acerca a um conceito único de existência. Continua Crescas:

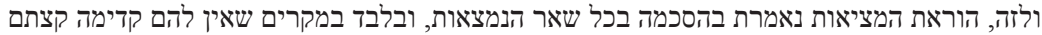
על קצתם, ויאמר בעצם ובמקרים בסיפוק. למה שהמציאות שהת חוץ לשכל, יאמר בקדימה בעצם, ובאחור

במקרים.

Desse modo, a existência é dita convencionalmente com respeito a todos os entes em geral. Tanto com relação aos acidentes (mikraim) que mantêm entre si uma relação hierárquica de prioridade uns com relação aos outros, de maneira que [a existência] é predicada à essência e aos acidentes de forma anfibológica (be-sipuk). É porque a existência se manifesta fora do intelecto ( hutz la-sekhel) que ela será dita em prioridade (be-kadimá) em relação à essência e em posteridade (uve-ahor) em relação aos acidentes. $(\mathrm{OH}, 1,3,1,2011)$

A formulação de Crescas do conceito de existência afasta-se não apenas de Avicena, Maimônides e Averróis, mas também dos escolásticos latinos que se referiam a uma existência no intelecto, por exemplo, dos entes matemáticos, e a outra existência na realidade, como os entes materiais. Crescas, no entanto, não chega a formular uma teoria completa da relação entre intuição, percepção e intelecto, mas fica claro que, para ele, a constatação da existência envolve uma operação que não se restringe ao pensamento. A quididade pode ou não se manifestar como existência determinada, mas, quando assim se dá, ela é encontrada (nimtzá) por vias além do intelecto. ${ }^{5}$ Esse modo próprio de manifestação da quididade (mahut), que se dá em determinadas condições para além do intelectivo, é a existência. Crescas chega assim a um conceito geral de existência, usado tanto para se referir à manifestação da essência (etzem) quanto à dos acidentes (mikrim), deixando claro que há diferença de grau de prioridade ontológica entre a existência da essência e a dos acidentes. Contudo, o conceito de existência é fundamentalmente o mesmo, aplicado 
tanto a um quanto a outro. A existência é, portanto, um conceito ambíguo que relaciona diferentes níveis de ser. Ela é dita em prioridade da essência e em grau menor dos acidentes.

Depois de ter tentado avançar uma conceituação positiva de existência, Crescas, talvez por não ter desenvolvido uma teoria da relação entre intelecto, intuição e percepção, ou seja, do que significa de modo mais claro para ele o hutz la-sekhel, o para fora do intelecto, retrai-se para uma definição geral negativa de existência. Nesse contexto, ele então enuncia seu conceito geral de existência:

אבל אמנם ההוראה הכוללת היא, היות הדבר המיחס לו המציאות - בלתי נעדר.

Contudo, o significado geral é que aquilo ao qual é atribuído da existência não é privado/carente [de realidade/de forma] (bilti needar). $(\mathrm{OH}, 1,3,1,2011)$

Aqui temos em Crescas uma definição da existência pela via negativa que, em princípio, faz lembrar um recurso semelhante usado por Maimônides para afirmar a inexistência de atributos divinos, uma vez que, para Maimônides, atributos positivos predicados a Deus são incompatíveis com sua unidade absolutamente simples e sem partes e imaterial. No entanto, o intelecto humano continua atribuindo predicados a Deus no intuito de buscar abarcá-lo com o pensamento. É nesse contexto que Maimônides se utiliza da tese dos atributos negativos ao afirmar que, ao negar o que Deus não é, avançamos pela via negativa um conhecimento de Deus à medida que ideias errôneas sobre a divindade são deixadas de lado. Ainda que esse método não leve ao conhecimento da quididade divina, a tese maimonidiana afirma que ainda assim é possível, por esse caminho, afastar o intelecto daquilo que não é Deus. De certa forma, ao definir pela via apofática ou negativa a existência como o que é privado ou carente de realidade, de atualidade, Crescas parece estar fazendo uma operação semelhante ao que Maimônides faz quando usa o conceito de atributo negativo, mas de fato Crescas está fazendo outra operação. O que ele tenta por essa via é enunciar um conceito mínimo de existência que pode ser aplicado a diferentes modos da atualidade de o ser se manifestar. É dessa maneira minimalista que Waxman entende e interpreta seu enunciado do conceito de existência. Escreve ele: "The general conception, however, must be understood in a negative way. The thing we predicate existence of is to be understood not non existing" (1920, p. 64). Chegar a um conceito único e geral de existência rompe com a noção aviceniana segundo a qual a existência de Deus - e, portanto, sua substância - é completamente externa e sem nenhuma relação com a existência do mundo e totalmente 
dissociada dela. Para Maimônides, entre Deus e o mundo há uma ruptura. Por outro lado, para Crescas, há certamente diferença de grau e primazia, mas não completa ruptura, como ele mesmo exemplifica ocorrer entre a substância e seus acidentes ou modificações. Nesse debate, Espinosa radicalizará, duzentos e cinquenta anos depois, a posição de Crescas.

O termo hebraico usado por Crescas nessa passagem para denotar inexistência é נעדר (needar), cujo sentido mais usual é ausência, falta ou privação. No jargão filosófico hebraico medieval, esse termo foi usado para se referir ao inexistente, ao transitório, ao que passou ou desapareceu (Heschel, 1941). Também heeder העדר, outro termo da mesma raiz, é usado no hebraico filosófico medieval para denotar privação, inexistência e aquilo que não é, mas poderia vir a ser. A palavra needar é consistentemente usada em várias traduções para o hebraico de textos filosóficos escritos em árabe com esse mesmo sentido. Por exemplo, na tradução hebraica do original árabe do Sefer Emunot Vedeot, Saadia Gaon (séc. X), needar é utilizado na passagem como oposto de matzui, o existente (Saadia Gaon, 2011). O termo também é usado em diversas passagens na tradução hebraica do Guia dos Perplexos, amplamente divulgada no tempo de Crescas para indicar falta ou privação de forma (tzurá). ${ }^{6}$ Gersônides (séc. XIV), que viveu em Avignon e Perpignan, e escreveu diretamente em hebraico, usa diversas vezes o mesmo termo em seu "Sefer Milhamot Ha-Shem" para indicar também privação de forma e inexistência. ${ }^{7}$ Vemos assim que needar, no hebraico, é usado comumente nos textos filosóficos medievais judaicos para indicar o contrário de termos como matzui, isto é, aquilo cuja existência é em ato, e tzurá, forma. Interessante é que esse uso também ocorre em literaturas sapienciais judaicas medievais não filosóficas; por exemplo, o "Perush Otzar Hashem", um dos comentários do Sefer Yetzirá, descreve como needar hatzurá, ou seja, privada de forma ou informe, a condição da criatura antes de sua criação.

Crescas usa o termo needar cerca de vinte vezes ao longo de "Or Hashem". Nessas diversas passagens, o termo sempre está associado à ideia de privação e de carência. Assim, por exemplo, em $O H$ 1,1,23, ele afirma que é necessário que um corpo esteja em estado de privação de algo no momento de sua transformação (needar baet ma). Em $O H$ 1,2,1, Crescas rejeita a noção de que o corpo infinito tenha forma circular ao afirmar que tal corpo seria carente de

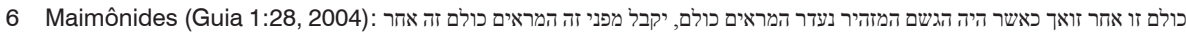
המציאה 1:49 - Ver também Guia מה שלא יפול ברשת הדמיון - אצלו נעדר ונמנע:

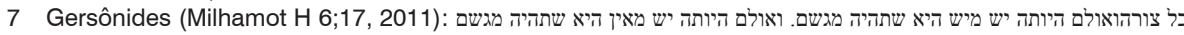

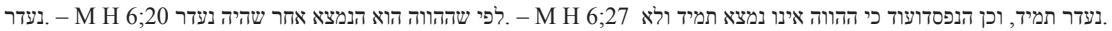


extremidades (needar ha-ketzvot). Em $O H$ 3,1,3, é usada a expressão "privada de toda forma" (needar mikol tzurá) para descrever a matéria primeira em sua condição inicial. Para Crescas, o conceito de metziut, existência, está intimamente ligado ao de realidade e de atualidade e determinação.

Smilevitch aponta que a palavra needar usada por Crescas e também na literatura filosófica medieval hebraica corresponde à stéresis aristotélica, que, nos textos latinos medievais, é traduzida como privatio. Na "Física" 7, 190b, Aristóteles apresenta a stéresis como um dos princípios dos entes naturais junto com a matéria primeira e a forma. Segundo ele, a stéresis é a essência do indeterminado. Na "Física" I, 191a-191b, o substrato permanente e a passagem de uma forma para sua contrária demandam a existência de uma carência stéresis da forma contrária no substrato. O uso por Crescas de needar em diversas passagens de "Or Há-Shem" está de acordo com essa observação de Smilevitch, no entanto, a descrição feita por Crescas da existência como privação ou carência de realidade ou de forma (bilti needar) parece mais próxima da stéresis neoplatônica que da aristotélica. Plotino entende o não ser como privação (Enéadas II, IV, 14). Assim, por exemplo, segundo ele, o mal não é uma substância; é na verdade a stéresis, ou seja, a privação do bem (Enéadas I, VIII, 11).

Vemos, desse modo, que Crescas, por meio de dois enunciados paralelos, busca um conceito mínimo, porém unificado, da existência aplicável por anfibologia tanto à essência quanto aos acidentes. $O$ primeiro enunciado conceitua a existência como uma das manifestações da quididade cuja característica é se dar fora do intelecto, e o segundo se refere à existência como "não carência" ou não privação de realidade. Seu passo seguinte será estender essa anfibologia a Deus e aos seres em geral. É desse modo que Crescas então escreve:

ובדרך הזה בעצמו יאמר בקדימה בו יתברך , ובאחור על שאר הנמצאות. ולזה הוא מבואר , שלא יאמר ה"נמצא" עליו ועל שאר הנמצאים בשימה בשיתוף השם גמור גמר, אלא במין הספוק.

E por essa via a existência é atribuída em prioridade de Deus, abençoado seja, e secundariamente aos outros entes. É assim esclarecido que a "existência" não é predicada a Deus e aos outros seres por uma completa homonímia, mas como um tipo de anfibologia. $(\mathrm{OH} 1,3,1)$

Afirmar que o conceito de existência é anfibológico é dizer que ele é ambíguo, ou seja, que pode ser aplicado a diferentes graus de realidade que não compartilham entre si a mesma quididade, mas que se manifestam de modo semelhante como atualidade para além do intelecto. Essa ambiguidade 
da existência, no entanto, é hierarquizada numa gradação de prioridade ontológica entre eles. Assim, ela é predicada a Deus em primeiro lugar, pois sua existência é necessária, isto é, independe de causa. Em segundo lugar, é também predicada aos seres em geral, pois sua existência é apenas contingente, isto é, sua causa é externa a eles. É por esse caminho que Crescas rejeita a tese da homonímia do conceito de existência, isto é, da radical transcendência divina em relação ao mundo. Não há uma ruptura absoluta, existir ocorre num contínuo entre Deus, os seres e seus acidentes. Somente a quididade divina permanece inacessível e, por isso mesmo, transcendente. No entanto, com relação à sua existência, certa imanência e comunidade de ser são desveladas.

\section{A prova da existência de Deus}

A discussão acerca da relação entre quididade e existência em Deus e nos seres em geral é a última etapa do percurso trilhado por Crescas até o enunciado de sua prova para a existência de Deus. Outros passos prévios nesse trajeto foram suas críticas à terceira das 26 proposições aristotélicas e à terceira prova para a existência de Deus, ambas apresentadas por Maimônides no início da segunda parte do "Guia dos Perplexos".

Basicamente a terceira proposição aristotélica no "Guia" II afirma que a existência de uma série infinita de causas e efeitos é impossível, ainda que não sejam magnitudes; por exemplo, mesmo um intelecto também não pode ser a causa de um segundo, e este, por sua vez, a causa de um terceiro, e assim por diante até o infinito. ${ }^{8}$ Os comentaristas medievais dessa proposição explicaram-na por duas vias paralelas: a aviceniana e a averroísta. Segundo o comentário de matriz aviceniana (Avicena, 2007, pp. 211-216), feito por A1Tabrizi, na Pérsia, durante o século XIII, admitindo-se a distinção entre ser necessário e ser contingente, uma série infinita não pode existir porque causa é aquilo cuja existência implica a existência do efeito e, se fosse concebida a não existência da causa, o efeito também não existiria. ${ }^{9}$ Sendo assim, conclui-se que a série infinita é impossível, pois, se o efeito tem apenas uma existência possível, por si mesmo ele precisa de um determinante que faça preponderar a tendência para sua existência sobre a inexistência (hedero): ${ }^{10}$

כן שקר מבוארהשלישית שמציאות עלות ועלולים אין תכלית למספרם שקר, ואע"פ שלא יהיו בעלי שעור, והמשל בו שיהיה השכל הזה על דרך

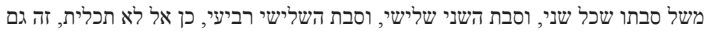

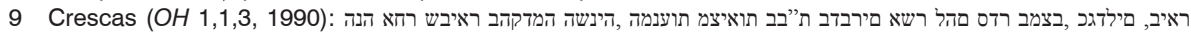

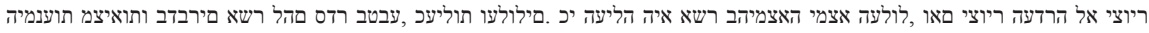
לולעה תואיצמ. רוצמיה

10 Literalmente, em hebraico: falta de forma, estado amorfo. 
esse determinante é sua causa. Logo, inevitavelmente, numa série infinita de causas e efeitos, ou todos os elementos são efeitos, ou alguns não são. Se todos forem efeitos, eles têm apenas existência possível, então não há o fator que determina a existência da série. Por outro lado, se um dos elementos da série infinita é apenas causa, sem ser efeito, então ele deve estar no começo da série, o que faz consequentemente com que esta já não seja infinita, pois tem uma primeira causa que a gera. O corolário dessa argumentação contra a atualidade infinita de causas e efeitos é a conclusão da necessidade de existir uma primeira causa não causada.

Segundo o comentário de matriz averroísta, que Crescas cita em nome de Moisés Narboni, aquilo que não pode ser realizado senão por meio de uma anterioridade causal infinita que o preceda nunca chegará a ocorrer e nunca existirá $(O H$ 1,2,3, 1990). O argumento é o seguinte: numa série causal infinita, todos os elementos são causa, assim como também são efeito, e, por serem todos efeitos, eles têm apenas existência possível. Deixando de lado o problema da necessidade de existir uma primeira causa incausada, se todos os elementos têm apenas existência possível, então cada um pode existir ou não até gerar o efeito seguinte à série. Se um dos elos da série não gerar o seguinte, a série acaba. Todavia, dada uma antecedência ou temporalidade infinita, todas as possibilidades já ocorreram; portanto, a possibilidade da descontinuidade da série já teria ocorrido, e a série causal já teria sido descontinuada. Assim, conclui Narboni, por essa via, uma série infinita de causas e efeitos nunca poderia ser de fato atual.

Crescas responde a esses dois argumentos que buscam embasar a rejeição à possibilidade de existir uma série atual infinita de causas e efeitos contra-argumentando que, em primeiro lugar, Maimônides reconhece que a causa primeira poderia gerar infinitos efeitos. Desse modo, os efeitos, por sua vez, poderiam estar ordenados em sucessão uns aos outros. Mesmo sendo simultâneos à causa primeira, os efeitos poderiam manter entre si uma causalidade acidental infinita, pois a anterioridade da primeira causa é ontológica e não necessariamente temporal. Dessa forma, é possível conceber o ser necessário, a primeira causa incausada, como simultâneo a infinitos efeitos que formam entre si uma série causal infinita. Tal série infinita está eternamente a ser gerada pela primeira causa que é imanente à série toda. A conclusão de Crescas é de que o único argumento dos aristotélicos medievais que fica de pé é aquele que afirma a necessidade de existir uma primeira causa não causada. Desse modo, o universo poderia ser eterno, pois poderia ser fruto da criação ou emanação constante da primeira causa, que é primeira em sentido ontológico. 
A chamada por Crescas de terceira prova de Maimônides para a existência de Deus menciona três possibilidades sobre a existência das coisas:

הכרחית, והוא אם שיהיו הנמצאות כלם בלתי הוות ולא נפסדות, (ג"א או כלם הוות ונפסדות) או יהיו קצתם הוה נפסד, וקצתם בלתי הוה ולא נפסד.

Ou nenhuma destas coisas tem início e fim, ou todas elas têm início e fim, ou algumas têm e outras não têm início e fim. (Maimônides, Guia 2, 1, 2004)

No "Guia", Maimônides argumenta que a primeira possibilidade é obviamente falsa, pois vemos coisas sendo geradas e sendo corrompidas e deixando de existir. A segunda possibilidade é também falsa porque, de acordo com essa hipótese, todas as coisas deveriam caminhar para seu fim e, desse modo, o mundo terminaria por já ter deixado de existir, o que também é obviamente falso. Assim, a única possibilidade que resta é a terceira:

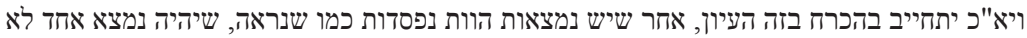

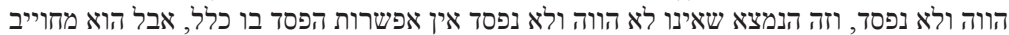

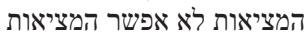

Consequentemente, é necessário, segundo essa especulação, que, desde que existam seres que sem dúvida são gerados e corrompidos, deve existir também um ser eterno que não está sujeito à geração nem à corrupção, e cuja existência é necessária e não meramente contingente. (Maimônides, Guia 2, 1, 2004)

A crítica de Crescas à terceira prova aponta que Maimônides se contradiz, pois havia escrito no "Guia" que buscaria provar a existência de Deus sem se utilizar da vigésima sexta proposição aristotélica, que afirma a eternidade do movimento, isto é, do tempo. Para Maimônides, junto com a criação do mundo (hidush há-olam) é também criado o tempo, que desse modo não poderia ser eterno. O tempo assim teria um começo, um primeiro momento de fiat lux. No entanto, a argumentação maimonidiana por trás da terceira prova pressupõe que já passou um tempo infinito e tudo não chegou ao fim. Maimônides necessita, portanto, daquela mesma proposição que ele diz rejeitar para poder sustentar seu argumento (Harvey, 1998, pp. 77-88). Além disso, como nota Harvey (1998, p. 86), a terceira prova também está em contradição com a terceira proposição, que rejeitaria uma cadeia de causalidade infinita, pois, ainda que se argumentasse que a verdadeira posição de Maimônides é em prol da eternidade do mundo, haveria uma contradição interna na argumentação do "Guia".

Depois de trilhar esse caminho, Crescas então enuncia sua prova da existência de Deus: 
אם שיהיו עלות ועלולים בעלי תכלית או בב "ת, אין הימלט, מהיות עילה אחת לכללם. למה שאם היו

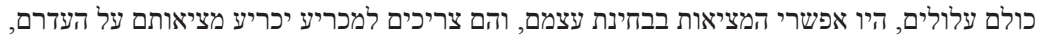
והיא העלה לכלם המכרעת מציאותם, והוא האל יתברך.

Independentemente de a série de causas e efeitos ser finita ou infinita, não há outra possibilidade a não ser a existência de uma causa (primeira) para todos. Pois, se todos são efeitos, eles têm apenas, em si mesmos, existência contingente (possível). Assim, eles necessitam (dependem) de um (fator) determinante capaz de outorgar (determinar) sua existência em detrimento de sua não existência, sendo desse modo a causa (primeira) da totalidade deles que determina sua existência. Este ser é Deus, bendito seja ele. $(O H 1,3,2,2011)$

O enunciado da prova para a existência de Deus em Crescas é ao mesmo tempo elegante e sintético. Depois de ter percorrido o caminho da crítica a vários aspectos das bases que sustentam as provas para a existência de Deus em Maimônides, tendo demonstrado não apenas a possibilidade do infinito atual, mas também a necessidade não declarada da eternidade do tempo para sustentar a prova maimonideana, ainda que o conjunto das causas e efeitos fossem finitos, como sustentam os filósofos aristotelizantes árabes e judeus, ou infinitos, como ele busca provar, em qualquer um dos casos é necessário que exista uma causa primeira, que é Deus. A necessidade da existência da causa primeira é fundamentada na distinção entre ser necessário e ser contingente. $\mathrm{O}$ ser necessário não precisa de causa externa a si para existir, por isso ele é eterno. Segundo Crescas, sua existência é um dos atributos essenciais de sua quididade. Na discussão sobre os atributos divinos, que vem em seguida, Crescas procura sustentar que eles são infinitos. Todavia, os seres contingentes, por serem apenas possíveis em relação à sua causa, necessitam de um fator que determine sua existência em detrimento de sua inexistência, levando-os da mera possibilidade à atualidade. Interessante é que Harvey (1998) nota que a prova de Crescas foi antecipada por Avicena em uma passagem da "Al-Najat" ("A Salvação"), em que o filósofo persa, apesar de negar o infinito em ato, baseando-se na distinção por ele introduzida entre existência contingente e necessária, afirma que a necessidade de uma causa primeira colocar-se-ia ainda que a série de causas e efeitos fosse infinita. A diferença entre Avicena e Crescas está no fato de um negar e o outro afirmar a atualidade da série causal infinita. É por afirmá-la que Crescas enfatiza que a causa primeira tem uma anterioridade ontológica não temporal em relação aos infinitos efeitos que constituem a metziut, ou seja, o universo infinito. A causa primeira é assim simultânea aos efeitos e, por isso mesmo, perpassa toda a extensão e o desenrolar-se da série causal infinita. Essa ênfase e seu corolário, isto é, o aspecto imanente da causa primeira em relação à série causal infinita, 
que constitui a realidade, são parte da contribuição que Crescas apresenta na construção argumentativa que está por trás do enunciado de sua prova. $\mathrm{O}$ outro aporte é aquele que vem da distinção entre quididade e existência, com base no qual Crescas define a existência como um dos atributos essenciais da essência divina e, portanto, não completamente idêntico à sua quididade. $\mathrm{Na}$ discussão que faz a seguir sobre a unidade divina, em crítica aberta ao "Guia dos Perplexos", Crescas afirma serem os atributos essenciais infinitos. O importante, no entanto, para sua prova, é que a existência recebeu uma conceituação comum tanto à essência quanto aos acidentes, tanto ao ser necessário quanto aos contingentes, ou seja, em sua definição geral, o existente é aquilo que, ao mesmo tempo, é para além do intelecto e não está carente de atualidade. Assim, a existência da causa primeira, determinante para a existência dos seres possíveis, tem, ainda que por uma anfibologia que estabelece uma relação de primazia e posteridade ontológica, uma substância comum. A existência de Deus é em grau superlativo e infinito aquilo que a existência dos entes é em grau comum e finito; contudo, trata-se da mesma existência. Sua quididade é transcendente enquanto sua existência é imanente. A ideia de infinito desempenha, desse modo, um importante papel na teologia e na ontologia de Crescas. Ainda de acordo com Harvey (1998), trata-se da primeira formulação de uma prova ontológica na filosofia judaica.

\section{Referências}

AVICENNA. "Metaphysics"” of the Salvation". In: J. Mc Ginnis; D. Reisman (eds.). Classical Arabic Philosophy: An Anthology of Sources. Indianapolis/Cambridge, Hackett Publishing Company, 2007. pp. 211-219.

CRESCAS, H. "Or Hashem" (Shlomo Fisher editor). Jerusalem: Sefrei Ramot, 1990. "Sefer Or Hashem: Há-Otzar Sefarim Há-Yehudi Versão 16", DBS, Jerusalem, 2011, em CD.

FREUNDENTHAL, G. "L'heritage de La physique stöicienne dans La pensée juive mediévale (Saadia Gaon, lês dévots rhénans, Sefer Há-Maskil)". Revue de Metaphysique et de Morale, Paris, Presses Universitaires de France, n. 4, 1998.

GERSÔNIDES . Sefer Milhamot Há-Shem em Há-Otzar: Há-Otzar Sefarim HáYehudi Versão 16, DBS, Jerusalem, 2011, em CD.

HARVEY, W. Z. "Physics and Metaphysics in Hasdai Crescas". Amsterdam: J.C. Gieben Publisher, 1998. pp. 77-88. (Amsterdam Studies in Jewish Thought).

HESCHEL, A. J. "A Concise Dictiorany of Hebrew Philosophical Terms". Cincinnati: Hebrew Union College, 1941. (mimeografado).

IBN EZRA, A. “Comentário Logo Há-Otzar Sefarim Há-Yehudi”, Versão 16, DBS, Jerusalem, 2011, em CD. 
MAIMÔNIDES. “Guia dos Perplexos, I, 57 em Bar-Ilan Judaic Library,” Version 11 Full Library (Responsa Project). Universidade Bar-Ilan/Torah Educational Software, Monsey, 2004, em CD.

. "Guia dos Perplexos em Há-Otzar: Há-Otzar Sefarim Há-Yehudi Versão 16." Jerusalem: DBS, 2011a, em CD.

"Milot Há-Higaion em Há-Otzar: Há-Otzar Sefarim Há-Yehudi Versão 16," DBS, Jerusalem, 2011b.

PLOTINO. "Enneads". Chicago, London, Toronto. In: Enciclopaedia Britannica, Inc. Willian Benton (Publisher), 1955.

RASHI. "Comentário ao Pentateuco em Bar Ilan Judaic Library", Version 11 - Full Library (Responsa Project), Universidade Bar-Ilan e Torah Educational Software, Monsey, 2004, em CD.

SAADIA GAON. "Sefer Emunot Vedeot em Há-Otzar: Há-Otzar Sefarim Há-Yehudi Versão 16." Jerusalem: DBS, 2011, em CD.

SMILEVITCH, E. "Prefácio e notas sobre Crescas em Lumière de L'Eternel". Paris: Éditions Hermann, 2010.

WAXMAN, M. "The Philosophy of Don Hasdai Crescas". Nova York: Columbia University Press, 1920.

WOLFSON, H. A. "Crescas on the Problem of Divine Attributes". J.Q.R., n. 7, pp. 1-44, 175-221, 1916.

. "Cresca's Critique of Aristotle". Cambridge: Harvard University Press, 1929,

1971. pp. 114-126. 